\title{
Efek Agitasi Susu Probiotik yang ditambahkan Buah Naga Merah (Hylocereus polyrhizus) terhadap Uji Sensorik dan Total Plate Count
}

\author{
(Effects of Milk Probiotic Agitation Added Red Dragon Fruit (Hylocereus Polyrhizus) on \\ Sensory Test and Total Plate Count)
}

\author{
Yusdar Zakaria ${ }^{1}$, Yurliasni $^{1}$, Feby Zalika Parindra ${ }^{1}$ \\ ${ }^{1}$ Program Studi Peternakan, Fakultas Pertanian, Universitas Syiah Kuala
}

\begin{abstract}
Abstrak. Suatu penelitian telah dilakukan untuk mengetahui efek agitasi susu probiotik yang ditambahkan buah naga merah (Hylocereus Polyrhizus). Penelitian ini dilakukan di Laboratorium Ilmu dan Teknologi Pengolahan Susu Fakultas Pertanian Universitas Syiah Kuala pada tanggal 29 April - 31 Mei 2016. Penelitian ini menggunakan Rancangan Acak Lengkap (RAL) pola faktorial 2x4 dengan 3 kali ulangan yang terdiri dari 2 faktor, A, agitasi yaitu (A1) dan (A2) non agitasi. Dan faktor B yaitu konsentrasi buah naga merah (B1) 20\%, (B2) $25 \%$, B3 (30\%) dan (B4) 35\%. Parameter yang diamati adalah derajat keasaman (pH), total mikroba dan uji organoleptik. Hasil penelitian menunujukkan bahwa terdapat pengaruh yang sangat nyata $(\mathrm{P}<0,01)$ terhadap derajat keasaman $(\mathrm{pH})$ dan berpengaruh nyata terhadap total mikroba $(\mathrm{P}<0,05)$ serta terdapat interaksi antara kedua perlakuan. Sedangkan untuk uji organoleptik terdapat pengaruh yang sangat nyata $(\mathrm{P}<0,01)$ terhadap kekentalan dan warna susu probiotik. nilai derajat keasaman $\mathrm{pH}$ 4,03 - 4,11 dengan agitasi (pengadukan) masih sesuai dengan standar (SNI) 01-2981-1992. Sedangkan nilai total mikroba optimal terjadi pada penambahan buah naga sebanyak $30 \%$ baik agitasi maupun non agitasi.
\end{abstract}

Kata kunci : Probiotik, buah naga merah, agitasi, sensorik, total plate count

\begin{abstract}
A study about effects of milk probiotic agitation added red dragon fruit (Hylocereus Polyrhizus) has been conducted to determine to test sensory and total plate count. This research was held at the Laboratory of Science and Milk Processing Technology, Agriculture Fakulty Syiah Kuala University on April 29 to May 31, 2016. This study used a completely randomized design (CRD) $2 \times 4$ factorial design with three replications consisting of two factors, A, agitation (A1) and (A2) non agitation. And factor B is the concentration of red dragon fruit (B1) 20\%, (B2) 25\%, B3 (30\%) and (B4) 35\%. The observed parameter is the degree of acidity $(\mathrm{pH})$, total microbial and organoleptic tests. The results of the study indicate that the there is a highly significant influence $(\mathrm{P}<0,01)$ to the degree of acidity $(\mathrm{pH})$ and total significantly affected the total microbial $(\mathrm{P}<0.05)$, and there is interaction between the two treatments. As for organoleptic tests are highly significant effect ( $\mathrm{P}$ $<0.01$ ) the thickness and color of probiotic milk. acidity pH value of 4.03 to 4.11 with agitation (stirring) is still in accordance with the standard (SNI) 01-2981-1992. While the total value of optimal microbial occurred upon addition of dragon fruit by $30 \%$ both agitation and non agitation.
\end{abstract}

Keywords: Probiotic, red dragon fruit, agitation, sensory, total plate count

\section{PENDAHULUAN}

Probiotik adalah mikroorganisme hidup yang ditambahkan ke dalam bahan pangan dengan tujuan untuk memberikan efek menguntungkan bagi kesehatan pada sistem pencernaan. Salah satu kelompok bakteri yang banyak digunakan sebagai probiotik yaitu kelompok Bakteri Asam Laktat (BAL), namun demikian tidak semua BAL dapat berperan sebagai probiotik (Havenaar dan Veld, 1992). Susu probiotik dapat dibuat dengan menggunakan susu dari jenis ternak ruminansia besar maupun kecil salah satunya susu kambing. Susu kambing adalah minuman kaya gizi. Dari keluhan-keluhan kesehatan yang sering dijumpai akibat mengkonsumsi susu sapi tidak ditemui pada orang yang mengkonsumsi susu kambing. Oleh karenanya, susu kambing bisa menjadi alternatif bagi konsumen yang alergi terhadap susu sapi (Budiana dan Susanto, 2005). Kandungan nutrisi susu kambing antara lain mineral, dan protein yang mudah di cerna. Susu kambing banyak di gunakan dalam pembuatan susu fermentasi. 
Yoghurt merupakan salah satu produk susu fermentasi yang telah lama dikenal dan mempunyai rasa asam yang spesifik. Yoghurt mempunyai nilai gizi yang lebih baik dari pada susu segar sebagai bahan dasar dalam pembuatan yoghurt, selain itu yoghurt sesuai bagi penderita Lactose Intolerance (Wahyudi, 2006).

Produk susu fermentasi seperti susu probiotik yang beredar dipasaran, pada umumnya banyak menggunakan tambahan buah-buahan yang segar untuk menambah cita rasa dan nilai gizi susu fermentasi tersebut. Seperti penambahan dengan buah naga merah. Buah naga merah memiliki rasa yang manis, buah naga juga memiliki banyak kandungan vitamin didalamnya seperti vitamin B1, B2, dan B3 selain itu buah naga memiliki kandungan antioksidan yang sangat baik untuk menangkal radikal bebas didalam tubuh. Buah naga merah juga memiliki pewarna alami yang dapat meningkatkan daya tarik konsumen.

Berdasarkan teksturnya, yoghurt terbagi dalam beberapa jenis yaitu, set yoghurt, merupakan yoghurt dengan tekstur sangat kental, umumnya warnanya putih dan terasa sangat asam. Stir yoghurt merupakan jenis yoghurt yang memiliki tekstur yang lebih encer dibanding set yoghurt tetapi masih terasa kental seperti es krim. Stir yoghurt dibuat dengan cara diaduk menggunakan mixer (Tamime dan Robinson 1985). Pengadukan pada stir yoghurt biasanya bertujuan untuk membuat campuran yoghurt lebih homogen, dan memperbaiki tekstur yoghurt.

Agitasi merupakan sistem pengadukan, pengadukan ini dilakukan untuk menghasilkan campuran yang homogen. Pencampuran dengan sistem agitasi ini sangat penting untuk transfer oksigen dalam fermentasi aerobik. Selain untuk memenuhi kebutuhan oksigen pada mikroba, agitasi juga berfungsi untuk menjaga mikroba tetap tersuspensi dan larutan medium tetap homogen (Tamime dan Robinson 1985). Penelitian ini bertujuan untuk mengetahui cita rasa, nilai $\mathrm{pH}$ dan jumlah bakteri susu probiotik yang diagitasi dan ditambahkan buah naga merah (Hylocereus polyrhizus).

\section{METODE PENELITIAN}

Penelitian ini telah dilakukan di Laboratorium Ilmu dan Teknologi Pengolahan Susu Program Studi Peternakan Fakultas Pertanian Universitas Syiah Kuala. Pada tanggal 29 April31 Mei 2016.

\section{MATERI DAN METODE}

Materi yang digunakan dalam penelitian ini adalah susu kambing, buah naga merah (Hylocereus polyrhizus), susu skim dan bakteri asam laktat (Lactobacillus achidophilus dan lactobacillus casei).

\section{Prosedur Kerja}

a. Pembuatan bubur buah naga merah

Buah naga dikuliti dan dicuci hingga bersih, kemudian dipotong dan dihaluskan dengan menggunakan blender untuk di dapatkan sari buah naga. Selanjutnya sari buah naga merah dipasturisasi pada suhu $50^{\circ} \mathrm{C}$ selama 15 menit dengan menggunakan waterbath sehingga menjadi bubur buah naga.

b. Pembuatan sampel minuman susu probiotik buah naga merah (hylocereus polyrhizus) non agitasi dan agitasi.

Susu kambing di pasturisasi dan didinginkan. Kemudian tambahkan susu skim sebanyak $5 \%$ setelah itu lakukan penambahan bubur buah naga merah sesuai perlakuan $(20 \%, 25 \%$, 30\%, 35\% ). Kemudian tambahkan starter L.casei dan L. acidophillus sesuai perlakuan (2,5\% $+2,5 \%$ ), Selanjutnya di inkubasi pada suhu $37^{\circ} \mathrm{C}$ selama 10 jam. Pada sampel susu probiotik 
yang diagitasi, agitasi dilakukan setelah 5 jam diinkubasi, kemudian di agitasi dengan menggunakan sendok steril. Selanjutnya diinkubasi kembali selama 5 jam.

\section{Parameter}

Parameter yang diamati adalah analisa nilai $\mathrm{pH}$, total bakteri asam laktat, dan uji organoleptik.

\section{Analisis nilai pH}

$\mathrm{pH}$ meter dikalibrasi terlebih dahulu dengan menggunakan larutan penyangga $\mathrm{pH} 4,7$ dan 9 pada suhu $20^{\circ} \mathrm{C}$. Kemudian $\mathrm{pH}$ sampel diukur dengan memasukkan elektroda $\mathrm{pH}$ meter ke dalam botol berisi sampel. Catat angka yang tertera pada $\mathrm{pH}$ meter.

\section{Analisis jumlah Mikroorganisme}

Media PCA (Plate Count Agar) dilarutkan ke dalam aquadest kemudian di sterilkan menggunakan Autoclave dengan suhu $121^{\circ} \mathrm{C}$ dengan waktu 15 menit. Kemudian lanjutkan pengenceran sampai pengenceran $10^{6}$. Ambil $1 \mathrm{ml}$ suspensi $10^{6}$ masukkan ke dalam cawan petri dan ditambahkan $20 \mathrm{ml}$ PCA steril cair kemudian di goyang secara rotasi hingga media merata dan dibiarkan sampai media menggumpal. Kemudian diinkubasi dalam inkubator pada suhu $37^{\circ} \mathrm{C}$ (letakkan cawan petri secara terbalik) Hitung jumlah coloni yang tumbuh setelah 48 jam dengan menggunakan colouny counter dan dengan menggunakan rumus menghitung jumlah bakteri

$$
(\mathrm{CFU} / \mathrm{ml})=\text { jumlah bakteri yang tumbuh } \mathrm{x} \frac{1}{\text { faktor pengencer }}
$$

\section{Uji Organoleptik}

Uji organoleptik di lakukan menggunakan panca indera manusia untuk mengukur rasa, viskositas (kekentalan), aroma, warna, serta penilaian secara keseluruhan yang dilakukan oleh 25 orang panelis. Dengan skala hidronik 1-5, Angka 1 menyatakan sangat tidak suka, 2 menyatakan tidak suka, 3 menyatakan agak suka, 4 menyatakan biasa, 5 menyatakan suka.

\section{Analisa Statistik}

Penelitian ini menggunakan metode Rancangan Acak Lengkap (RAL) pola faktorial yang terdiri dari faktor, A agitasi yaitu, $\left(\mathrm{A}_{1}\right)$ agitasi dan $\left(\mathrm{A}_{2}\right)$ non agitasi, faktor $\mathrm{B}$ yaitu konsentrasi buah naga merah $\left(B_{1}\right) 20 \%,\left(B_{2}\right) 25 \%,\left(B_{3}\right) 30 \%$ dan $\left(B_{4}\right) 35 \%$. Setiap perlakuan diulang 3 kali sehingga diperoleh 24 satuan unit percobaan. Data di analisa menggunakan anova, jika terdapat perbedaan antara perlakuan dilanjutkan dengan Uji Jarak Berganda Duncan. (Steel dan Torrie, 1993)

\section{HASIL DAN PEMBAHASAN}

\section{Nilai pH}

Hasil analisis ragam menunjukkan bahwa agitasi berpengaruh sangat nyata $(\mathrm{P}<0,01)$ terhadap nilai $\mathrm{pH}$ serta terdapat interaksi diantara kedua perlakuan Gambar 1. Berdasarkan Uji Jarak Berganda Duncan menunjukkan bahwa nilai $\mathrm{pH}$ susu probiotik dengan agitasi dengan penambahan buah naga $20 \%$ tidak berbeda dengan penambahan $25 \%$ buah naga, namun berbeda dengan nilai $\mathrm{pH}$ susu probiotik dengan penambahan $30 \%$ dan $35 \%$ buah naga. Sedangkan nilai $\mathrm{pH}$ susu probiotik non agitasi tidak berbeda antar perlakuan 


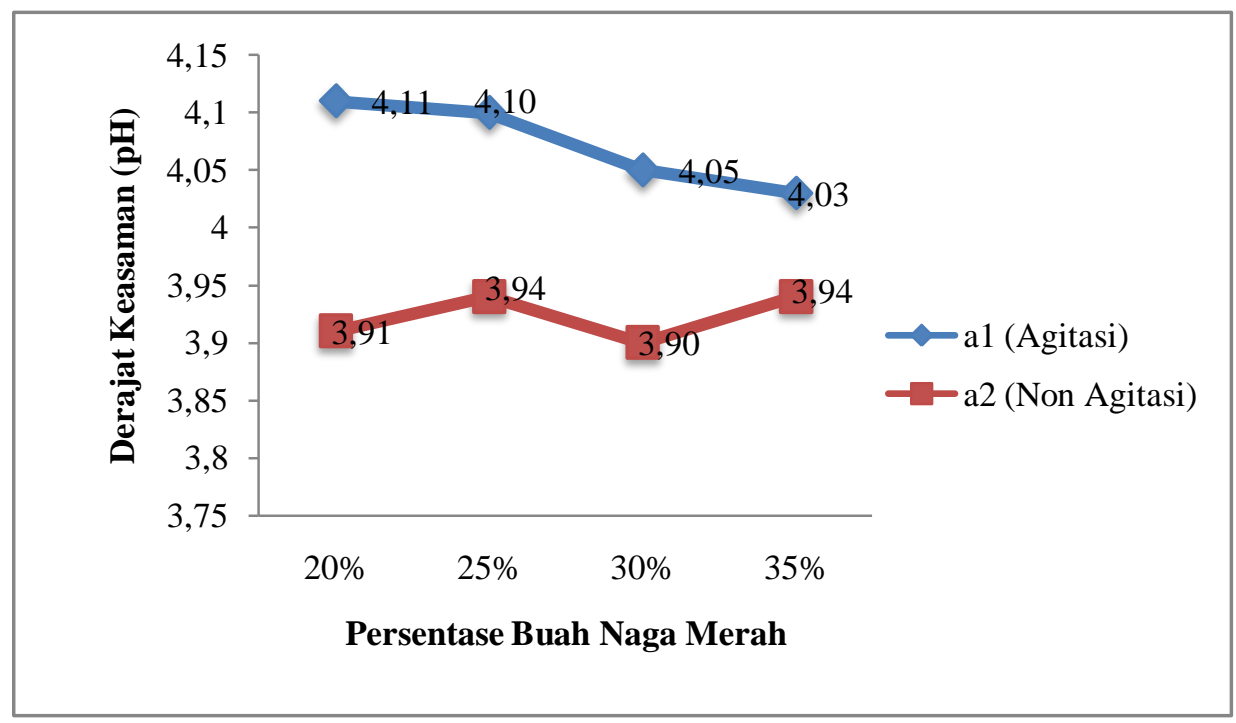

Gambar 1. Kurva Nilai pH Susu Probiotik Buah Naga Merah

Gambar 1 menunjukkan bahwa nilai $\mathrm{pH}$ terendah $(3,90)$ terdapat pada perlakuan non agitasi dengan penambahan buah naga merah $30 \%$. Hal ini diduga karena penambahan buah naga 30\% merupakan persentase maksimal yang dapat ditolerir oleh BAL dalam menurunkan nilai $\mathrm{pH}$ pada susu probiotik. Pada perlakuan non agitasi nilai $\mathrm{pH}$ lebih rendah dan total mikroba menurun, hal ini diduga karena adanya beberapa enzim yang terlibat dalam proses fermentasi, dan tidak semua enzim bekerja pada karbohidrat. Sehingga sebagian besar enzim bekerja pada protein dan fruktosa. Hal ini sesuai dengan pendapat Bensmira dan Jiang (2011) selama proses fermentasi berlangsung, penurunan $\mathrm{pH}$ susu utamanya disebabkan oleh fermentasi asam laktat yang terjadi akibat kerja mikrobia yang mampu mengubah laktosa menjadi asam laktat.

\section{Total Mikroorganisme}

Hasil analisa sidik ragam menunjukkan bahwa perlakuan penambahan buah naga merah (Hylocerus polyrhizus) dengan agitasi dan non agitasi pada susu probiotik berpengaruh sangat nyata $(\mathrm{P}<0,01)$ terhadap jumlah total mikroba susu probiotik, serta terdapat interaksi antar kedua faktor (gambar 2).

Hasil Uji Jarak Berganda Duncan menunjukkan bahwa terdapat perbedaan antara perlakuan penambahan buah naga pada level yang berbeda. Terdapat perbedaan antara penambahan buah naga merah sebanyak $30 \%$ (8,35 x log 10). Dengan penambahan buah naga $20 \%(7,57 \times \log 10)$ dan $35 \%(7,10 \times \log 10)$. Terjadi peningkatan jumlah total mikroba pada persentase penambahan buah naga merah $20 \%$ - 30\%, sedangkan pada penambahan buah naga merah sebanyak $35 \%$ terjadi penurunan jumlah total mikroba. Hal ini diduga karena pada buah naga merah terdapat senyawa fenol yaitu flavonoid yang dapat menghambat pertumbuhan bakteri gram positif dan batas toleransi pertumbuhan mikroba hanya sampai pada penambahan buah naga sebanyak $30 \%$. 


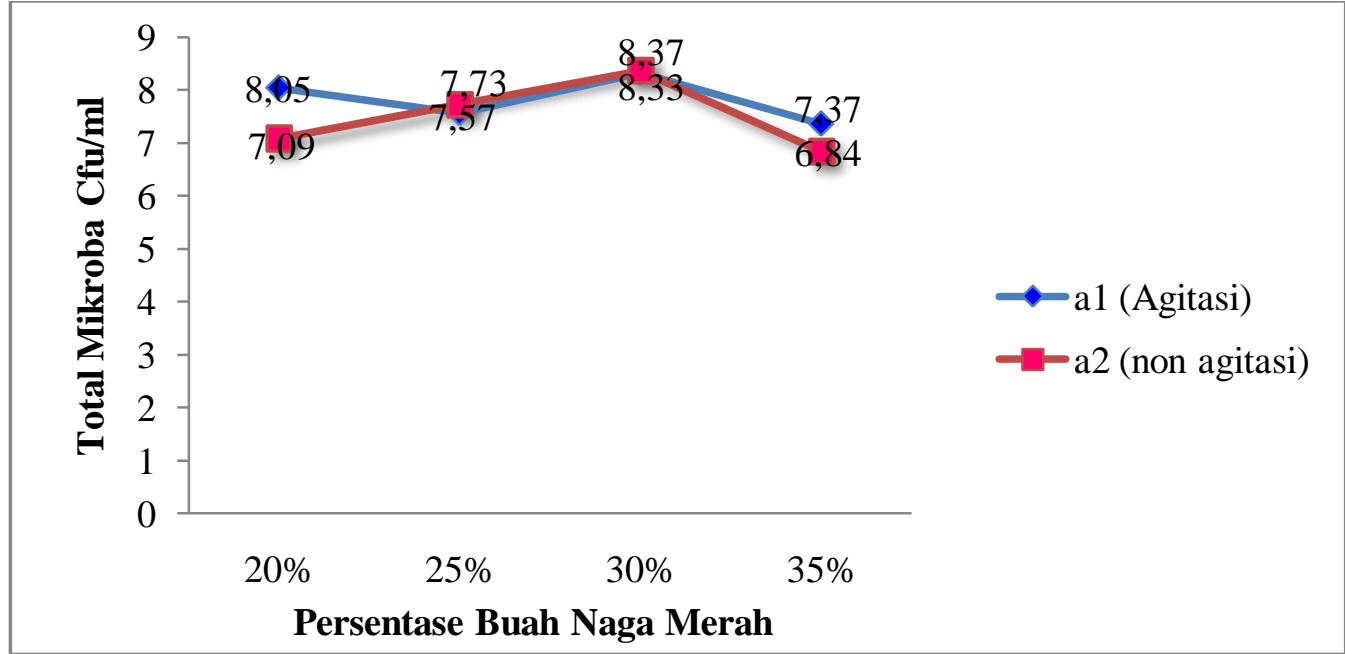

Gambar 2. Kurva Total Mikroba Susu Probiotik Buah Naga Merah (Log 10)

Jumlah total mikroba tertinggi terdapat pada penambahan $30 \%$ buah naga merah. Hal ini diduga karena penambahan buah naga merah $30 \%$ baik agitasi dan non agitasi menunjukkan pertumbuhan optimal mikroba dan merupakan interaksi terbaik. Sedangkan pada penambahan buah naga sebanyak $35 \%$ terjadi penurunan total mikroba.

\section{Uji Rasa}

Hasil uji organoleptik terhadap parameter rasa susu probiotik buah naga merah menunjukkan tidak berpengaruh nyata $(\mathrm{P}>0,05)$ terhadap tingkat kesukaan rasa susu probiotik buah naga merah.

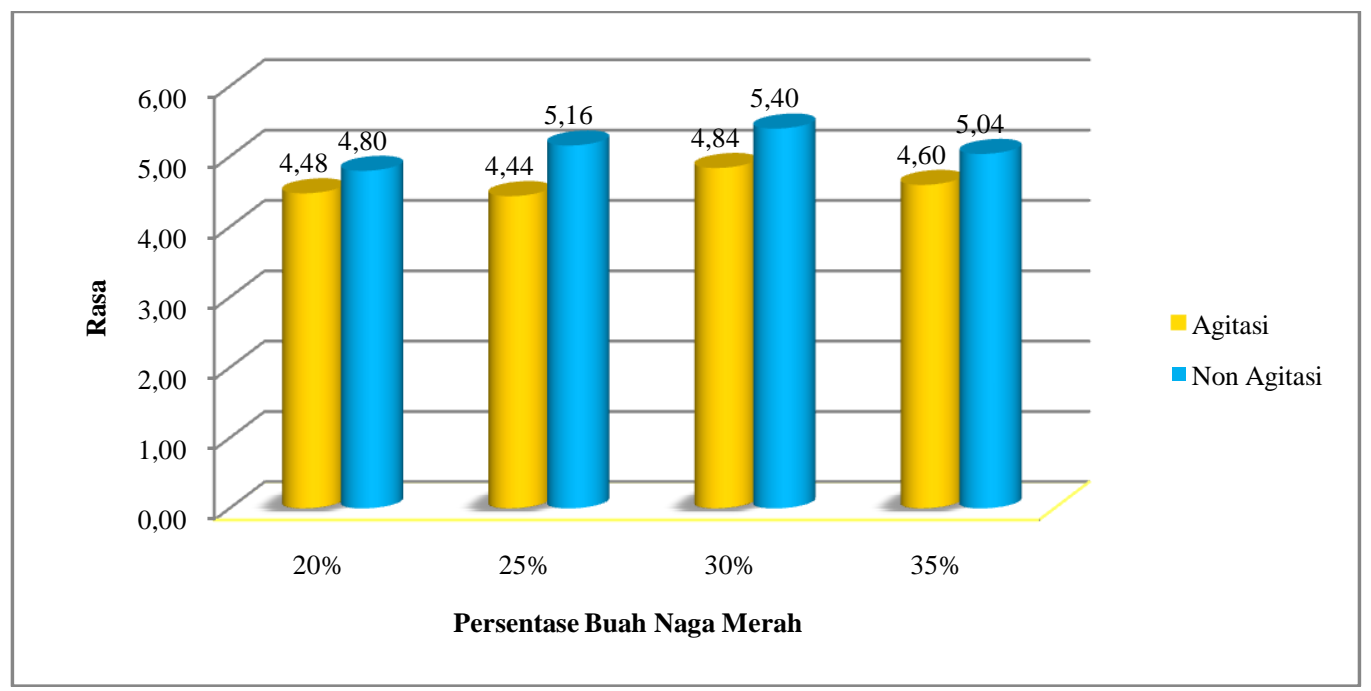

Gambar 3. Rerata Uji Rasa Susu Probiotik Buah Naga Merah (Hylocereus Polyrhizus) Dengan Agitasi Dan Non Agitasi

Gambar 3 menunjukkan bahwa panelis menyukai rasa susu probiotik yang tidak mengalami agitasi pada penambahan persentase buah naga $25 \%$ sampai dengan $35 \%$. karena rasa buah naga merah yang tidak terlalu asam, sehingga penambahan buah naga merah sebanyak $25 \%$ sampai dengan $35 \%$ pada susu probiotik non agitasi disukai oleh panelis. Hal ini sesuai dengan pendapat dari Widodo (2002) jenis buah yang cocok untuk dicampurkan dengan yogurt adalah yang manis untuk mengimbangi keasaman yogurt. 
Buah yang tidak terlalu manis tapi tidak terlalu asam juga dapat ditambahkan kedalam yoghurt.

\section{Uji Warna}

Hasil analisa sidik ragam menunjukkan bahwa tingkat kesukaan warna susu probiotik buah naga merah yang mengalami agitasi dan non agitasi berbeda sangat nyata $(\mathrm{P}<0,01)$.

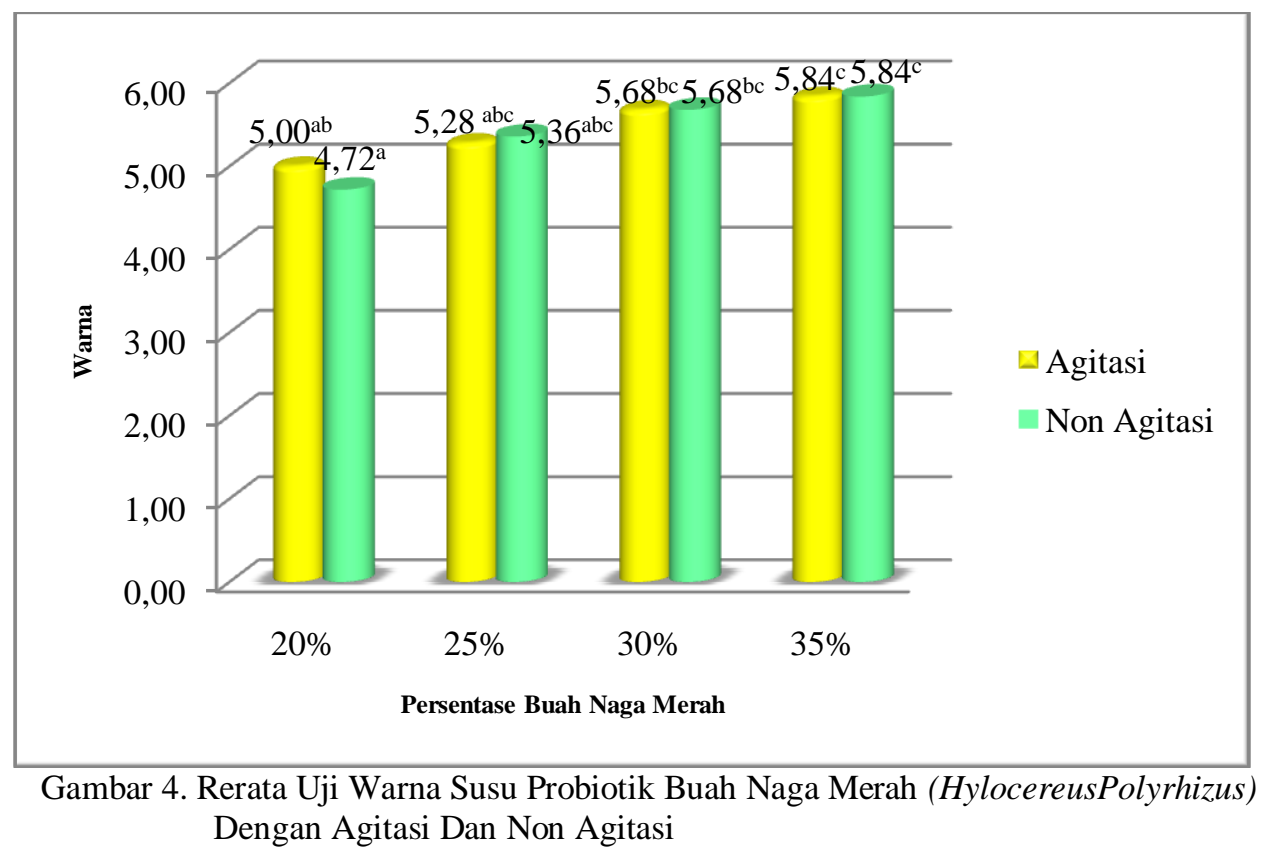

Berdasarkan Uji Jarak Berganda Duncan menunjukkan bahwa warna susu probiotik yang berbeda adalah antara warna susu probiotik dengan penambahan buah naga merah $35 \%$ baik agitasi maupun non agitasi dengan warna susu probiotik perlakuan lainnya. Hasil uji warna susu probiotik dengan penambahan buah naga merah yang mengalami agitasi menunjukkan bahwa warna yang disukai oleh panelis pada susu probiotik yaitu pada penambahan buah naga $20 \%$ sampai dengan $35 \%$. dan nilai tertinggi yaitu 5,84 pada penambahan buah naga merah sebanyak $35 \%$. Hal ini diduga karena warna pada penambahan $35 \%$ buah naga merah baik agitasi dan non agitasi memberikan warna yang menarik. Sehingga panelis menyukai warna dengan penambahan $35 \%$ buah naga merah baik agitasi dan non agitasi.

\section{Uji Aroma}

Hasil penelitian menunjukkan bahwa kesukaan panelis terhadap parameter aroma susu probiotik buah naga merah yang mengalami agitasi dan non agitasi tidak berbeda nyata $(\mathrm{P}>0,05)$. Gambar 6 menunjukkan panelis cenderung suka pada aroma susu probiotik dengan agitasi dan ditambahkan buah naga merah yaitu pada penambahan buah naga merah sebanyak $30 \%$. Sedangkan pada penambahan buah naga merah $20 \%, 25 \%$ dan 35\% panelis menilai biasa saja. Hal ini karena penambahan buah naga merah menyebabkan aroma yang khas dari buah naga itu sendiri yaitu agak manis sehingga menutupi aroma asam dari susu probiotik. 


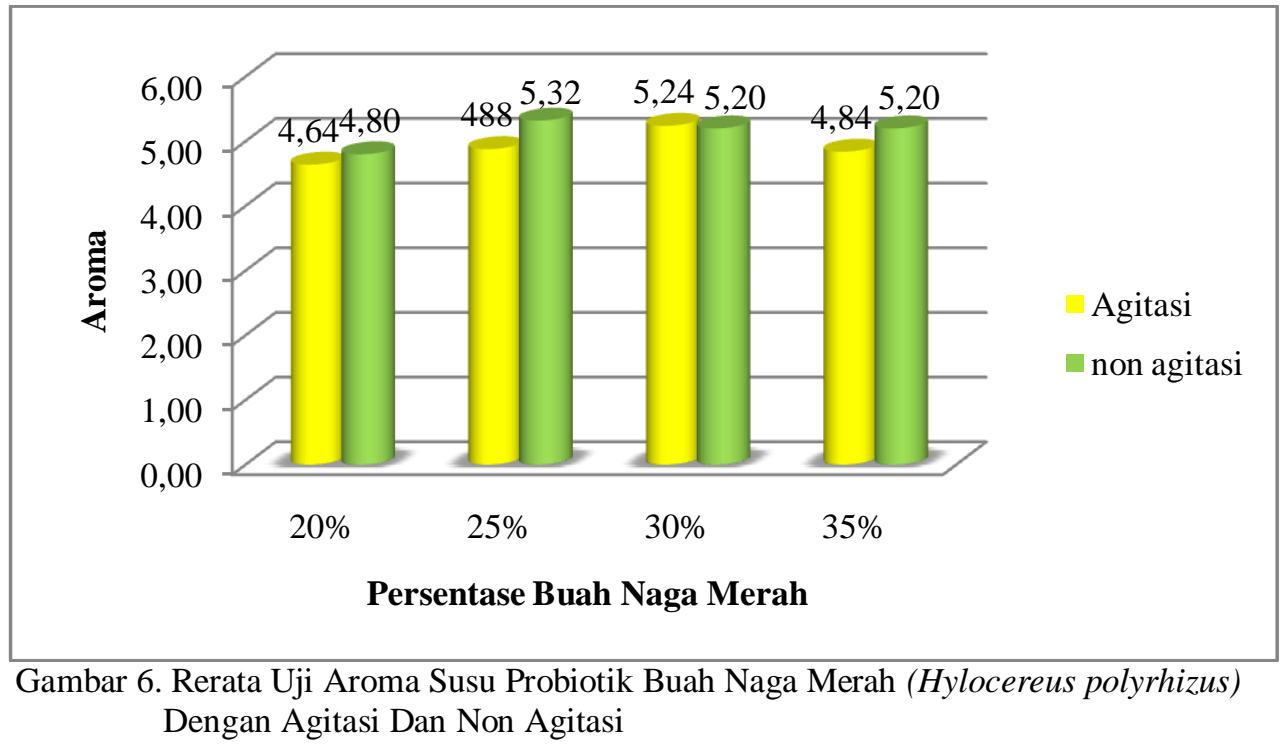

Setyaningsih (1992) menyatakan bahwa selama berlangsungnya fermentasi, terbentuk asam yang menyebabkan aroma yang khas serta komponen komponen citarasa lain seperti karbonil, asetaldehid, dan diasetil. Sedangkan pada perlakuan non agitasi panelis menyukai aroma susu probiotik dengan penambahan buah naga merah sebanyak $25 \%$ sampai dengan $35 \%$.

\section{Uji Kekentalan}

Data analisis sidik ragam menunjukkan bahwa tingkat kekentalan susu probiotik buah naga merah yang mengalami agitasi dan non agitasi berpengaruh sangat nyata $(\mathrm{P}<0,01)$ terhadap susu probiotik.

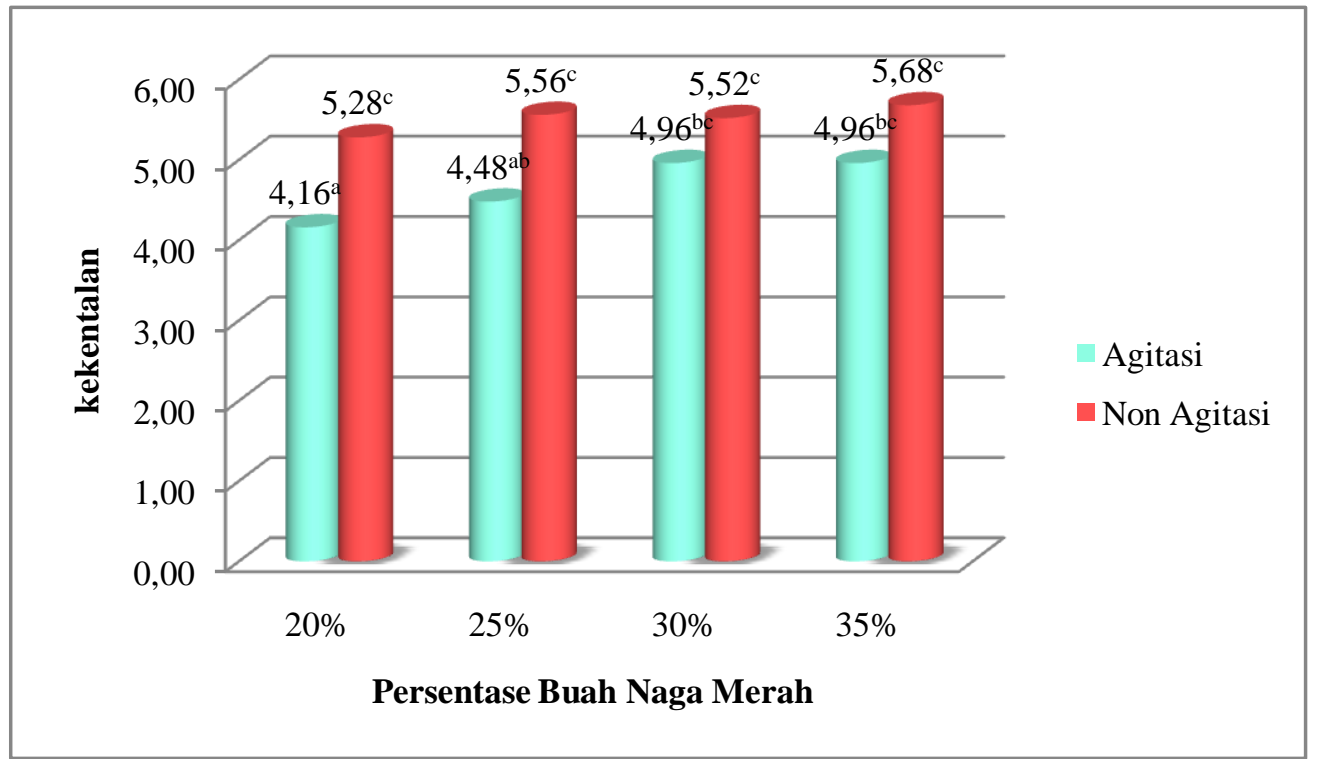

Gambar 5. Rerata Uji Kekentalan Susu Probiotik Buah Naga Merah (Hylocereus polyrhizus) Dengan Agitasi Dan Non Agitasi.

Hasil dari uji organoleptik terhadap parameter kekentalan susu probiotik buah naga merah non agitasi menunjukkan bahwa panelis lebih menyukai kekentalan susu probiotik dengan non agitasi yang ditambahkan buah naga merah 20\% sampai dengan 35\%. Dengan nilai rerata tertinggi yaitu 5,68 pada penambahan $35 \%$ buah naga merah. Hal ini diduga 
karena tekstur susu probiotik yang belum mengalami agitasi (pengadukan) lebih kental dibandingkan dengan perlakuan yang mengalami agitasi (pengadukan).

\section{KESIMPULAN DAN SARAN}

Susu probiotik yang ditambahkan buah naga merah $30 \%$ dengan agitasi dan non agitasi menunjukkan jumlah total mikroba tertinggi. Sedangkan nilai $\mathrm{pH}$ ) susu probiotik yang diagitasi menunjukkan semakin banyak penambahan buah naga semakin rendah nilai $\mathrm{pH}$ ), dan masih sesuai dengan Standar Nasional Indonesia (SNI). Rasa susu probiotik yang disukai adalah perlakuan non agitasi dengan penambahan buah naga merah $25 \%$ sampai dengan $35 \%$.

\section{DAFTAR PUSTAKA}

Badan Standarisasi Nasional. 1992. SNI 01-2891. Cara uji makanan dan minuman. Jakarta. Bensmira, M. dan B. Jiang. 2011. Organic acids formation during the production of a novel peanut sampai dengan milk kefir beverage. British J. of Dairy Science, 2 (1):18 sampai dengan 22.

Budiana, N, S Susanto, D. 2005.Susu kambing. Penebar swadaya, Jakarta. Hal.5

Havenaar, R. and Veld, H. 1992. Probiotic : General View. In : Word, B.J.b.1992. The lactic acid bacteria in health and disease. Elsevier Appl. Sci. London. Vol. 7 :151sampai dengan 170

Setyaningsih. I. 1992. Pengaruh jenis kultur L. casei. penambahan susu skim dan glukosa terhadap mutu yakult kedelai. Skripsi Fateta IPB. Bogor

Steel, R. G. D. Dan J. H. Torrie. 1993. Prinsip dan prosedur statistika ( pendekatan Biometrik) penerjemah B. Sumantri. Gramedia Pustaka Utama, Jakarta.

Tamime, A.F. and R. K. Robinson. 1985. Yoghurt, Sciense, and technology. Pergamon Press. New york.

Wahyudi, M. 2006. Proses pembuatan dan Analisis mutu yoghurt. Buletin Teknik Pertanian. Vol. 11 No. 1

Widodo, W. 2002. Bioteknologi fermentasi susu. Pusat Pengembangan Bioteknologi Universitas Muhammadiyah Malang. Malang. 29 hal. 